\title{
Invertebrates are declining in boreal aquatic habitat : The effect of brownification?
}

\section{Arzel, Celine}

2020-07-01

Arzel , C , Nummi , P , Arvola , L , Pöysä , H, Davranche , A, Rask , M , Olin , M , Holopainen, S, Viitala , R, Einola , E \& Manninen-Johansen, S 2020 , ' Invertebrates are declining in boreal aquatic habitat : The effect of brownification? ' , The Science of the Total Environment , vol. 724 , 138199 . https://doi.org/10.1016/j.scitotenv.2020.138199

http://hdl.handle.net/10138/315678

https://doi.org/10.1016/j.scitotenv.2020.138199

draft

Downloaded from Helda, University of Helsinki institutional repository.

This is an electronic reprint of the original article.

This reprint may differ from the original in pagination and typographic detail.

Please cite the original version. 


\section{Journal Pre-proof}

Invertebrates are declining in boreal aquatic habitat: The effect of brownification?

Céline Arzel, Petri Nummi, Lauri Arvola, Hannu Pöysä, Aurélie Davranche, Martti Rask, Mikko Olin, Sari Holopainen, Risto Viitala, Eeva Einola, Sanni Manninen-Johansen

PII: S0048-9697(20)31712-5

DOI: https://doi.org/10.1016/j.scitotenv.2020.138199

Reference: STOTEN 138199

To appear in: Science of the Total Environment

Received date: 15 November 2019

Revised date: 18 March 2020

Accepted date: 23 March 2020

Please cite this article as: C. Arzel, P. Nummi, L. Arvola, et al., Invertebrates are declining in boreal aquatic habitat: The effect of brownification?, Science of the Total Environment (2018), https://doi.org/10.1016/j.scitotenv.2020.138199

This is a PDF file of an article that has undergone enhancements after acceptance, such as the addition of a cover page and metadata, and formatting for readability, but it is not yet the definitive version of record. This version will undergo additional copyediting, typesetting and review before it is published in its final form, but we are providing this version to give early visibility of the article. Please note that, during the production process, errors may be discovered which could affect the content, and all legal disclaimers that apply to the journal pertain.

(C) 2018 Published by Elsevier. 
Invertebrates are declining in boreal aquatic habitat: the effect of brownification?

Co-authors: Céline Arzel ${ }^{1 \& 2}$, Petri Nummi ${ }^{2}$, Lauri Arvola ${ }^{3}$, Hannu Pöysä $\ddot{4}^{4}$, Aurélie Davranche ${ }^{5}$, Martti Rask ${ }^{3}$, Mikko Olin ${ }^{6}$, Sari Holopainen ${ }^{2}$, Risto Viitala ${ }^{7}$, Eeva Einola ${ }^{8}$ and Sanni ManninenJohansen ${ }^{8}$.

\title{
Affiliations:
}

1 Department of Biology, FI-20014 university of Turku, Finland,

2 Department of Forest Sciences, P.O. Box 27, University of Helsinki, FI-00014 Helsinki, Finland

3 University of Helsinki, Lammi Biological Station, FI-16900 Lammi, Finland 4 Natural Resources Institute Finland (Luke), Yliopistokatu 6, FI-80100 Joensuu, Finland 5 University of Angers, LETG-UMR CNRS 6554, 2 boulevard Lavoisier, FR-49000 Angers, France

6 Natural Resources Institute Finland (Luke), Latokartanonkaari 9, FI-00790 Helsinki, Finland

7 HAMK University of Applied Sciences Evo Campus, Forestry, Saarelantie 1, FI-16970 Evo, Finland

8 Vanajavesi Center, Perttulantie 84, FI-13430 Hämeenlinna, Finland

Emails:_celine.arzel@utu.fi,_ celine.arzel@helsinki.fi; petri.nummi@helsinki.fi; lauri.arvola@helsinki.fi; $\quad$ hannu.poysa@luke.fi; $\quad$ aurelie.davranche@univ-angers.fr; martti.rask@helsinki.fi; mikko.olin@luke.fi; $\quad$ sari.holopainen@helsinki.fi; Risto.Viitala@hamk.fi; eeva.einola@vanajavesi.fi; sanni.manninen.johansen@vanajavesi.fi.

Corresponding author: Céline Arzel; address: Natura, Vesilinnantie 5, FI-20014 Turku, Finland; Phone: +358408778636; emails: celine.arzel@utu.fi; celine.arzel@ helsinki.fi.

\begin{abstract}
:
Surface water browning affects boreal lakes in the Northern Hemisphere. This process is
\end{abstract}


expected to increase with global warming. Boreal lakes are the most numerous lakes on Earth. These ecosystems are particularly sensitive to disturbances due to their low biodiversity compared to other aquatic environments. The recent darkening of surface water is expected to hinder key ecosystem processes, particularly through lower primary productivity and loss of biodiversity. However, studies based on long-term data collections have rarely been conducted on the ecological consequences of water browning on aquatic food webs, especially concerning its impacts on invertebrate communities.

For the first time, our analysis based on two decades of data collection in Finnish lakes highlighted a relation between water browning and a decline in aquatic macroinvertebrate abundances. Aquatic invertebrates are the main food resource for many secondary predators such as fish and waterbirds, hence such effect on their populations may have major consequences for boreal ecosystem functioning.

Keywords: aquatic invertebrates, brownification, abundance, richness, ecosystem functioning, water color. 


\section{Introduction}

During the last decades, temperate surface waters have become browner throughout the Northern Hemisphere (Monteith et al., 2007). This is known as the 'brownification' process. While the drivers of this change are not fully understood, concurrent increases in dissolved organic carbon and iron concentrations have been observed (Kritzberg \& Ekström, 2012). The transfer of dissolved organic matter into water is particularly strong in areas that have suffered most from acid rain in the past (Gavin et al., 2011). Changes in acid deposition modify soil chemistry, favoring a release of organic matter into water, especially under high precipitation regimes (De Wit et al., 2016). The European boreal area has been particularly affected by lake acidification. Climate change predictions project wetter and extreme weather events in this zone (De Wit et al., 2016). Hence, the browning of boreal and subarctic rivers and lakes is expected to progress over the entire Fennoscandian peninsula (the area that encompasses Norway, Finland and Sweden, along with the Murmansk province and the Republic of Karelia in Russia) (Jennings et al., 2010; Naden et al., 2010).

Boreal wetland ecosystems host few species compared to temperate and tropical ecosystems (Schindler, 1998), which makes their biodiversity particularly vulnerable to disturbances (Schindler, 1998). Brownification is expected to negatively impact the composition, structure, and function of aquatic food webs, as light conditions govern processes such as photosynthesis, system productivity (Karlsson et al., 2009), and predator-prey interactions (Ranåker et al., 2012; Lehtovaara et al., 2014). However, ecological consequences of brownification, especially its effects on aquatic food webs, have not been fully understood yet (but see Leech et al., 2018).

Invertebrates are a key element of terrestrial and aquatic food webs. Recent studies have shown a drastic decrease of terrestrial insects in Europe (Hallman et al., 2017) and at the global 
scale (Dirzo et al., 2014). These studies have raised concerns about the functioning of the whole terrestrial ecosystem. In contrast, there is a lack of long-term data on freshwater invertebrates (Jackson \& Füreder, 2006; Gozlan et al., 2018). In particular, the status of aquatic macroinvertebrate populations in lakes has rarely been assessed for large scale processes linked to global changes. A recent exception from the European boreal area is Fried-Petersen et al. (2020) who studied long-term stability of invertebrate communities in Swedish lakes in relation to environmental (alkalinity and total phosphorous) and physical (lake size and latitude) variables. Aquatic invertebrates are a food resource for many organisms such as fish, amphibians, and waterbirds. Thus, changes in their populations may have major consequences at the lake or wetland scale but also at a larger scale. Fennoscandian lakes are the most important waterbird breeding areas in Europe (e.g. Hagemeijer \& Blair, 1997). Invertebrates are the main food resource for many waterbird species during reproduction. They constitute the main part of juvenile waterbird diets, especially during their first weeks of life (Sugden, 1973; Nummi et al., 2013). Changes in food availability may have dramatic consequences for the survival and breeding outcome of waterbirds.

Light penetration in the water column decreases due to the browning of surface water (Kritzberg et al., 2020). It directly affects primary production. Many aquatic invertebrate species are herbivorous and rely on plant cover to hide from predators. Decreased light penetration may affect zooplankton community compositions and dynamics (Lehtovaara et al., 2014; Estlander et al., 2017), the search efficiency of visual feeders, and thereby their consumption rates (Horppila et al., 2011; Estlander et al., 2012; Jönsson et al., 2013). Surface water browning causes stronger temperature stratification leading to lower oxygen concentrations in the hypolimnion with a reduction in the oxythermal habitat of aquatic biota (Couture et al., 2015). Although Urrutia- 
Cordero et al. (2017) documented a decline in phytoplankton along a gradient of water browning, no studies on the effects of brownification on macroinvertebrate abundance and richness have been conducted yet.

Here, we assessed the change in water color over time in 20 lakes for which data have been collected over three decades. We evaluated the role of precipitation as a driver of water color change over time in our study area. We tested the effect of water color change on the macroinvertebrate abundance and richness of five lakes where both water color and invertebrate surveys had been conducted in the area. We predicted an increase in water color over time related to a decline of invertebrates both in terms of abundance and richness.

\section{Material and Methods}

\subsection{Study area and surveys}

The study area is located in southern Finland, in the Evo Natura 2000 area $\left(61^{\circ} 120 \mathrm{~N}\right.$, $25^{\circ} 070 \mathrm{E}$, Fig. 1). Its $7854 \mathrm{~km}^{2}$ of surface encompasses 136 lakes of varying sizes (from 0.01 to 50.3 hectares) covering $2 \%$ of the area. Boreal coniferous and mixed forests, mostly in commercial use for timber harvesting, cover respectively 56\% and 40\%. Transitional wood shrub accounts for $2 \%$ of the surface of the whole studied zone. Agriculture $(<1 \%)$ only occurs in the vicinity of a few lakes. The Evo area is sparsely populated. The area has a long history of forest and environmental monitoring. Since four decades, several research projects in aquatic sciences have been carried out there.

The surface water color of the Evo lakes has been monitored as part of water quality surveys conducted at the Lammi Biological Station and by the Finnish Natural Resources Institute since the early 1990s. Data on water color were analyzed for 20 lakes during surveys ranging from 
nine to 31 years (mean $\pm \mathrm{SD}=27.4 \pm 6.3$ years; Table S1; Fig. 1). These lakes have been sampled each year at the end of October or during the first week of November, which corresponds to the autumnal turnover of the lakes before freezing (Salonen et al., 1984). Sampling campaigns are carried out during a one-week period at most, including all the lakes. The samples are kept cold, in the dark, and transported to the Lammi Biological Station laboratory immediately after sampling. The laboratory is located $20 \mathrm{~km}$ from the study area. Thus, the analyses are performed on fresh samples. Water color is expressed in milligrams of platinum per liter (mg Pt/L). Precipitation is recorded monthly at Lammi Biological Station since the 1990s. The average annual precipitation is the mean of monthly precipitation from November year t-1 to October year t, i.e. covering 12 months before the yearly fall water color survey in November.

Our analysis linking invertebrate parameters and water color focused on five typical oligotrophic boreal lakes, out of the 20 studied lakes. These five lakes had available data for the period from 1990 to 2008 (Fig. 1). All five lakes are surface water-fed lakes. Data available for each lake are detailed in the supplementary material (Table S1). When present, the emergent vegetation zone surrounding the lakes is narrow and mainly consists of Carex sp. and Phragmitesaustralis.

Invertebrate trapping was conducted at the beginning of June each year from 1989 to 2008, in the frame of a study concerning the availability of food resources for Anas spp. ducks at the early brood stage. Activity traps (see Murkin et al., 1983) were used to capture free-swimming aquatic invertebrates. An activity trap consists of a 4-liter glass jar and a white plastic funnel with a 140$\mathrm{mm}$ opening at the largest end and a 20-mm opening at the narrowest end. Activity traps were horizontally suspended at a water depth of $20-40 \mathrm{~cm}$ close to the shoreline. This position allows 
assessing food availability at a reachable depth for duck species occurring in these environments. Activity traps allow catching both benthic and pelagic invertebrates (Elmberg et al., 1992; Hyvönen and Nummi, 2000; Table S2). Four activity traps per lake allowed to collect invertebrates during one week. Following the protocol of Nummi \& Pöysä (1993), traps were emptied onto a 1-mm mesh size sieve then remaining invertebrates were sorted, identified, and counted. The total number of individuals (hereafter "invertebrate abundance") was calculated as the sum of individuals collected in the four traps for each year and lake. Invertebrates were identified up to the order, family, or genus (Table S2); hence, "invertebrate richness" is the total number of taxa identified in the four traps for each year and lake.

\subsection{Statistical analyses:}

All statistical analyses were performed using program R ( $\mathrm{R}$ version 3.6.2 (2019-04-26), R Core Team, 2019). R package 'lattice' (Sarkar, 2008) was used for graphical edition. 'Ime4' (Bates et al., 2015) was used for generalized mixed model analyses. Year was included as a co-variate in some of the following models (specified below), in order to control for potential temporal correlation in the models. Lake ID was used as a random effect in all models to account for the non-independence of samples within lakes. Predictor variables were scaled and centered prior to analyses.

Water color changes of the 20 lakes, and of the five lakes, over time were assessed by linear mixed models with lake as a random effect. The effect of precipitation on the water color of the 20 lakes over time was tested with a linear mixed model with year as a co-variate and lake as a random effect. In these three models the water color response variable was square root transformed to meet the criteria of residual normality. 
The effect of water color on invertebrate abundance over time, was tested with a generalized mixed Poisson model with year as a co-variate and lake as a random effect. The Poisson GLMM was slightly overdispersed with an overdispersion value of 1.26 . Other tested modeling approaches, such as the addition of a correction term to take into account the potential temporal autocorrelation, and other distribution families, lead to greater overdispersion and did not improve the model specification.

The effect of water color on invertebrate richness over time was tested with a linear mixed model with year as a co-variate and lake as a random effect.

The variance inflation factor (VIF) allowed estimating the multicollinearity between the predictor variables (Zuur et al. 2013) in the mixed models. The calculated VIF value ranged from 2.306 to 2.632 , so all predictors were kept in the models (Montgomery \& Peck 1992). Model assumptions (normal distribution of the residuals and homoscedasticity of the models) were visually confirmed (supplementary material S1-5, Zuur et al., 2009). For the mixed models, we provide both the Marginal $R^{2}\left(R_{\text {LMM }}^{2}(m)\right)$, which is the variance explained by fixed factors, and conditional $\mathrm{R}^{2}\left(\mathrm{R}_{\mathrm{LMM}}^{2}(\mathrm{c})\right)$, which is the variance explained by both fixed and random factors (Nakagawa \& Schielzeth 2013).

\section{Results}

Lake water color has increased in the 20 lakes since the early 1990s (intercept $=-374.686 \pm$ 23.738 , slope $=0.194 \pm 0.012, p<2 \mathrm{e}-16$, Table 1 , Fig. 2). The yearly average precipitation affects the water browning of the 20 lakes (intercept $=14.368 \pm 0.650$, slope $=0.929 \pm 0.091, p<2 \mathrm{e}-16$, Table 1). Nevertheless, it explains only a small share of the water color change $\left(\mathrm{R}_{\mathrm{LMM}}^{2}(\mathrm{~m})=\right.$ $\left.0.223, \mathrm{R}_{\mathrm{LMM}}^{2}(\mathrm{c})=0.719\right)$. 
A similar trend towards surface water browning was observed in the five lakes for which invertebrate data were available (intercept $=-477.046 \pm 38.587$, slope $=0.246 \pm 0.019, p<2 \mathrm{e}-$ 16, Table 1, Fig. 2). The water color increased by a factor of 1.8 at the five lakes during the invertebrate survey: from an average of $152.6 \pm 57.3$ (mean $\pm \mathrm{SD}$ ) $\mathrm{mgPt} / \mathrm{L}$ during the first decade of the invertebrate survey (1990-1998) to an average of $272.9 \pm 85.7 \mathrm{mgPt} / \mathrm{L}$ during the second decade (1999-2008) (Fig. 2). Water color has kept increasing during the last decade, reaching an average of $300 \pm 75.6 \mathrm{mgPt} / \mathrm{L}$ in these five lakes.

A total of twenty-six invertebrate taxa, including both benthic and nektonic invertebrates, were identified in our samples (Table S2). The decline in invertebrate abundance was associated with an increase of water color (intercept $=3.331 \pm 0.215$, slope $=-0.443 \pm 0.039, p<2 \mathrm{e}-16$, Table 1, Fig. 3a) but not with year (slope $=-0.058 \pm 0.033, p=$ NS, Table 1). However, our models did not support a negative impact of water color on invertebrate richness (intercept $=$ $4.349 \pm 0.303$, slope $=-0.101 \pm 0.260, p=$ NS, Table 1, Fig. $3 b)$ or year $($ slope $=-0.359 \pm 0.243$ $p=$ NS, Table 1).

\section{Discussion}

Invertebrates are crucial to ecosystem functioning, yet their rapid declines in the terrestrial environment (Dirzo et al., 2014; Hallman et al., 2017) has occurred nearly unnoticed, raising concern about potential invertebrate declines in various ecosystem types (Eisenhauer et al., 2019). Here, we document a clear decrease in aquatic invertebrate abundances in the studied boreal lakes during 1989-2008 associated with an increase in water browning. Boreal wetlands are particularly sensitive to perturbation (Schindler et al., 1998). The change in water color in the study lakes over the last 30 years is remarkable: all the surveyed lakes became browner. The 
change in water color is consistent with earlier observations made in the boreal zone (Evans, Monteith \& Cooper, 2005; Vuorenmaa, Forsius \& Mannio, 2006; Arvola et al., 2010; Kritzberg \& Ekström, 2012). Boreal lakes are the most numerous of any lake types on Earth (Schindler, 1998), thus the impact of browning will have large-scale consequences for boreal aquatic ecosystems and for global biodiversity and ecosystem functioning.

Reasons behind the increasing browning trends seen in most region's lakes are not fully understood. Arvola et al. (2010) highlighted the relation between hydrology, pH, sulfate deposition, and water color. Although precipitation has not dramatically changed in the long run, exceptionally high summer-autumn precipitation distinctly enhances color values (Arvola et al., 2006). Nevertheless, while an increase in precipitation contributes significantly to the increase in water color at the 20 studied lakes, it only partly explains the observed increase in water color. A strong decrease in sulfur deposition since the late 1980s, and changes in land-use and forestry practices in catchment areas may also have contributed to the increase in water color in the area (Arvola et al. 2010). Forestry activities are taking place at all catchment areas around the studied lakes, which may also affect the water color of the lakes (Arvola et al., 2010; Kritzberg, 2017). Further studies are needed to identify human practices promoting the release of organic matter into the aquatic system and to identify methods to remediate the negative impact of these practices.

Our study demonstrated an important impact of brownification on all aquatic macroinvertebrates. Water browning was not associated with a change in invertebrate taxonomic richness in our study. The data set did not allow us to estimate changes at the species level. Thus, we cannot exclude that brownification affects species differently. Nevertheless, the sharp decline of invertebrate numbers observed in our study may have tremendous impacts on the functioning 
of the entire ecosystem and call for further research on other levels of the food chain.

Brownification appears to negatively impact primary and secondary invertebrate consumers by altering their behavior (Estlander et al., 2017) but also by affecting their food resources (Vasconcelos et al. 2018), oxythermal and vegetative habitat, predator-prey relationships (Estlander et al., 2009, 2012), and biodiversity (Urrutia-Cordero et al., 2017). Certain changes in vegetation have been observed in our study area during the study: the major visible changes being the narrowing of emergent vegetation belts (mainly Carex) and the decline of horsetail Equisetum fluviatile (Suhonen et al., 2011; Pöysä et al., 2017). The reasons for these changes are unknown. Nevertheless, brownification and concurrent water warming are known to cause declines in macrophytes (Reitsema et al., 2018; Choudhury et al., 2019). Littoral zones are the most productive areas of boreal humic lakes and provide important basal food resource for lake biota (Kairesalo 1980, Vesterinen et al., 2017). Thus, changes in lake stratification and vegetation decline may have increased the predation pressure by fish in the littoral zone. Unfortunately, data on fish populations were only available for two of our five studied lakes and for a very limited time period, preventing us from drawing any firm conclusions on the potential effect of fish populations on invertebrates. Nevertheless, fish surveys from other lakes in the study area reveal that neither fish biomass nor abundance varied with water color change (Arzel et al. in prep.). Further research is needed to assess the current state of submerged vegetation and potential decline as consequences of brownification in our study area. The continuous increase of water color, even after the last invertebrate surveys in 2008 , calls for an urgent assessment of the status of aquatic macroinvertebrate community change in the lakes of this study area and elsewhere in boreal regions.

The decline of invertebrate abundance observed here is likely to affect the whole ecosystem, 
as invertebrates are the main food resource of organisms such as many fish species and ducks. A decline of invertivore duck species has occurred in boreal lakes during the period as our study (Pöysä et al., 2019; Elmberg et al., 2020). Our results call for further investigation of biodiversity loss in boreal lakes. In particular, biodiversity loss from boreal aquatic ecosystems deserves much more attention than it has so far received in the context of browning.

\section{Acknowledgements}

Céline Arzel was supported by a grant from the Finnish Cultural Foundation Häme Regional Fund and Sari Holopainen was supported by the Osk. Huttunen foundation. Two anonymous reviewers provided useful comments to improve the manuscript. We thank Stella Thompson for her English proofreading and comments, and Dr. Elie Gaget for constructive discussions on statistical analyses.

\section{Author contributions}

CA and PN designed the study. CA gathered and analyzed the data, with support and feedback from PN, SH \& LA. AD provided Figure 1. CA wrote the manuscript and all co-authors provided editorial revisions.

\section{Declaration of interest:}

We report that there are no personal or economic conflicts of interests. The authors have no competing interests to declare.

\section{Data accessibility statement:}


The data that support the findings of this study are available upon request from PN for the invertebrate databases and from LA for the water color databases.

\section{References}

Arvola, L., Järvinen, M. \& Hakala, I. (2006). Nutrient export from small boreal catchments: The influence of annual and seasonal hydrology. Verhandlungen des Internationalen Verein Limnologie, 29, 2031- 2034.

Arvola, L., Rask, M., Ruuhijärvi, J., Tulonen, T., Vuorenmaa, J., Ruoho-Airola, T. \& Tulonen, J. (2010). Long-term patterns in $\mathrm{pH}$ and colour in small acidic boreal lakes of varying hydrological and landscape settings. Biogeochemistry, 101, 269-279.

Bates, D., Maechler, M., Bolker, B. \& Walker, S. (2015). Fitting Linear Mixed-Effects Models Using lme4. Journal of Statistical Software, 67(1), 1-48. doi:10.18637/jss.v067.i01.

Benslimane, N., Khémissa, C., Haiahem D., Guelmami A., Samraoui F. \& Samraoui B. (2019). Anthropogenic stressors are driving a steep decline of hemipteran diversity in dune ponds in north-eastern Algeria. Journal of Insect Conservation, 23(3), 475-488.

Choudhury, M. I., Urrutia-Cordero, P., Zhang, H., Ekvall, M. K., Medeiros, L. R. \& Hansson, L.A. (2019). Charophytes collapse beyond a critical warming and brownification threshold in shallow lake systems. Science of the Total Environment, 661, 148-154. 
Couture, R.-M., de Wit, H. A., Tominaga, K., Kiuru, P. \& Markelov, I. (2015). Oxygen dynamics in a boreal lake responds to long-term changes in climate, ice phenology, and DOC inputs. Journal of Geophysical Research: Biogeosciences, 120, 2441-2456.

De Wit, H. A., Valinia, S., Weyhenmeyer, G. A., Futter, M. N., Kortelainen, P., Austnes, K., ... Vuorenmaa, J. (2016). Current Browning of Surface Waters Will Be Further Promoted by Wetter Climate. Environmental Science \& Technology Letters, 3 (12), 430-435.

Dirzo, R., Young, H. S., Galetti, M., Ceballos, G., Isaac, N.J.B. \& Collen, B. (2014). Defaunation in the Anthropocene. Science, 345(6195), 401-406.

Eisenhauer, N., Bonn, A. \& Guerra, C. A. (2019). Recognizing the quiet extinction of invertebrates. Nature Communications, 10, 50.

Elmberg, J., Nummi, P., Pöysä, H. \& Sjöberg, K. (1992). Do introducing predators affect the reliability of catches in activity traps? Hydrobiologia, 239, 187-193.

Elmberg, J., Arzel, C., Gunnarsson, G., Holopainen, S., Nummi, P., Pöysä, H. \& Sjöberg, K. (2020). Population change in breeding boreal waterbirds in a 25-year perspective: what characterizes winners and losers. Freshwater Biology, 65, 167-177.

Estlander, S., Nurminen, L., Olin, M., Vinni, M. \& Horppila, J. (2009). Seasonal fluctuations in macrophyte cover and water transparency of four brown-water lakes: implications for crustacean 
zooplankton in littoral and pelagic habitats. Hydrobiologia, 620, 109-120.

Estlander, S., Horpila, J., Olin, M. \& Nurminen, L. (2017). Should I stay or should I go? The diurnal behaviour of plant-attached zooplankton in lakes with different water transparency Journal of Limnology, 76(2), 253-260.

Estlander, S., Horppila, J., Olin, M, Vinni, M., Lehtonen, H., Rask, M. \& Nurminen, L. (2012). Troubled by the humics — effects of water colour and interspecific competition on the feeding efficiency of planktivorous perch. Boreal Environment Research, 17, 305-312.

Evans, C. D., Monteith, D. T. \& Cooper, D. M. (2005) Long-term increases in surface water dissolved organic carbon: observations, possible causes and environmental impacts. Environmental Pollution, 137, 55-71.

Fried-Petersen, H. B., Araya-Ajoy, Y. G., Futter, M. N. \& Angeler, D. G. (2020). Drivers of long-term invertebrate community stability in changing Swedish lakes. Global Change Biology, $26,1259-1270$.

Gavin, A. L., Nelson, S. J., Klemmer, A. J., Fernandez, I. J., Strock, K. E \& McDowell, W. H. (2018). Acidification and Climate Linkages to Increased Dissolved Organic Carbon in HighElevation Lakes. Water Resources Research, 54(8), 5376-5393.

Gozlan, R. E., Karimov, B. K., Zadereev, E., Kuznetsova, D. \& Brucet, S. (2019) Status, trends, 
and future dynamics of freshwater ecosystems in Europe and Central Asia. Inland Waters, 9:1, 78-94.

Hallmann, C. A., Sorg, M., Jongejans, E., Siepel, H., Hofland, N., Schwan, H., ... de Kroon, H. (2017). More than 75 percent decline over 27 years in total flying insect biomass in protected areas. PLoS ONE, 12(10), e0185809.

Hagemeijer, W. J. M. \& Blair, M. J. (1997). The EBCC Atlas of European Breeding Birds. Their distribution and abundance. (eds T. \& A.D. Poyser). London, pp. 903.

Horppila, J., Estlander, S., Olin, M., Pihlajamäki, J., Vinni, M. \& Nurminen, L. (2011). Genderdependent effects of water quality and conspecific density on the feeding rate of fish-factors behind sexual growth dimorphism. Oikos, 120, 855-861.

Hyvönen, T. \& Nummi, P. (2000). Activity traps and the corer: complementary methods for sampling aquatic invertebrates. Hydrobiologia, 432,121-125.

Jackson, J. K. \& Füreder, L. (2006). Long-term studies of freshwater macroinvertebrates: a review of the frequency, duration and ecological significance. Freshwater Biology, 51, 591-603.

Jansson, A. (1977). Micronectae (Heteroptera, Corixidae) as indicators of water quality in two lakes in southern Finland. Annales Zoologici Fennici, 14, 118-124. 
Jennings, E., Järvinen, M., Allott, N., Arvola, L., Moore, K., Naden, P., ... Weyhenmeyer, G. A. (2010). The impact of the changing climate on the flux of dissolved organic carbon from catchments. In: The Impact of Climate Change on European Lakes (Ed. D.G. George), Springer Verlag, pp. 199-220.

Jönsson, M., Ranåker, L., Nilsson, P. A. \& Brönmark, C. (2013). Foraging efficiency and prey selectivity in a visual predator: differential effects of turbid and humic water. Canadian Journal of Fisheries and Aquatic Sciences, 70, 1685-1690.

Karlsson, J., Byström, P., Ask, J., Ask, P., Persson, L. \& Jansson, M. (2009). Light limitation of nutrient-poor lake ecosystems. Nature, 460, 506-509.

Kritzberg, E. S. \& Ekström, S. M. (2012). Increasing iron concentrations in surface waters - a factor behind brownification?, Biogeosciences, 9, 1465-1478.

Kritzberg, E. S. (2017). Centennial- long trends of lake browning show major effect of afforestation. Limnology and Oceanography Letters, 2 (4), 105-112.

Kritzberg, E. S., Hasselquist, E. M., Škerlep, M., Löfgren, S., Olsson, O., Stadmark, J., Valinia, S., Hansson, L. A., Laudon, H. (2020). Browning of freshwaters: Consequences to ecosystem services, underlying drivers, and potential mitigation measures. Ambio, 49 (2), 375-390.

Leech, D. M., Pollard, A. I., Labou, S. G. \& Hampton, S. E. (2018). Fewer blue lakes and more 
murky lakes across the continental US: Implications for planktonic food webs. Limnology and Oceanography, 63(6), 2661-2680.

Lehtovaara, A., Arvola, L., Keskitalo, J., Olin, M., Rask, M., Salonen, K., ... Vuorenmaa, J. (2014). Responses of zooplankton to long-term environmental changes in a small boreal lake. Boreal Environment Research, 19, 97-111.

Monteith, D. T., Stoddard, J. L., Evans, C. D., de Wit, H. A., Forsius, M., Høgåsen, T.,... Vesely J. (2007). Dissolved organic carbon trends resulting from changes in atmospheric deposition chemistry. Nature, 450, 537-541.

Murkin, H. R., Abbott, P. G. \& Kadlec, J. A. (1983). A comparison of activity traps and sweep nets for sampling nektonic invertebrates in wetlands. Freshwater Invertebrate Biology, 2, 99106.

Naden, P., Allott, N., Arvola, L., Järvinen, M., Jennings, E., Moore, K.,... Schneiderman, E. (2010). Modelling the effects of climate change on dissolved organic carbon. In: The Impact of Climate Change on European Lakes (Ed. D.G. George). Springer Verlag, pp. 221-252.

Nakagawa, S. \& Schielzeth, H. (2013). A general and simple method for obtaining R2 from generalized linear mixed- effects models. Methods in Ecology and Evolution. 4 (2), 133-142.

Nummi, P. \& Pöysä, H. (1993). Habitat associations of ducks during different phases of the 
breeding season. Ecography, 16, 319-328.

Nummi, P., Paasivaara, A., Suhonen, S. \& Pöysä, H. (2013). Wetland use by brood-rearing female ducks in a boreal forest landscape: the importance of food and habitat. Ibis, 155(1), 6879.

Polhemus, J. T. \& Polhemus, D. A. (2008). Global diversity of true bugs (Heteroptera; Insecta) in freshwater. Hydrobiologia, 595, 379-391.

Pöysä, H., Elmberg, J., Gunnarsson, G., Holopainen, S., Nummi, P., \& Sjoberg, K. (2017). Habitat associations and habitat change: seeking explanation for population decline in breeding Eurasian wigeon Anas penelope. Hydrobiologia, 785(1), 207-217.

Pöysä, H., Holopainen, S., Elmberg, J., Gunnarsson, G., Nummi, P. \& Sjöberg, K. (2019). Longterm changes in species richness and composition of boreal waterbird communities. Scientific Reports, 9, 1725.

Ranåker, L., Jönsson, M., Nilsson, P. A. \& Brönmark, C. (2012). Effects of brown and turbid water on piscivore - preyfish interactions along a visibility gradient. Freshwater Biology, 57, $1761-1768$.

R Core Team (2018). R: A language and environment for statistical computing. R Foundation for Statistical Computing, Vienna, Austria. URL https://www.R-project.org/. 
Reitsema, R. E., Meire, P. \& Schoelynck, J. (2018). The Future of Freshwater Macrophytes in a Changing World: Dissolved Organic Carbon Quantity and Quality and Its Interactions With Macrophytes. Frontiers in Plant Science, 9, 629.

Salonen, K., Arvola, L. \& Rask, M. (1984). Autumnal and vernal circulation of small forest lakes in southern Finland. Verhandlungen des Internationalen Verein Limnologie, 22, 103-107.

Sarkar, D. (2008). Lattice: Multivariate Data Visualization with R. Springer, New York. ISBN 978-0-387-75968-5

Savage, A. A. (1982). Use of water boatmen (Corixidae) in the classification of lakes. Biological Conservation, 23, 55-70.

Schindler, D. W. (1998). Sustaining aquatic ecosystems in boreal regions. Conservation Ecology, 2(2), 18.

Sugden, L. G. (1973). Feeding ecology of pintail, gadwall, American wigeon and lesser scaup ducklings in southern Alberta. Canadian Wildlife Service Report Series, 24, 45 pp.

Suhonen, S., Nummi, P. \& Pöysä, H. (2011). Long term stability of habitats and use by ducks in boreal lakes. Boreal Environment Research, 16 (suppl. B), 71-80. 
Urrutia-Cordero, P., Ekvall, M. K., Ratcovich, J., Soares, M., Wilken, S., Zhang, H., ... Hansson, L. A. (2017). Phytoplankton diversity loss along a gradient of future warming and brownification in freshwater mesocosms. Freshwater Biology, 62 (11), 1869-1878.

Vasconcelos, F. R., Diehl, S., Rodríguez, P., Hedström, P., Karlsson, J. \& Byström, P. (2018).

Bottom- up and top- down effects of browning and warming on shallow lake food webs. Global Change Biology, 25 (2), 504-521.

Vesterinen, J., Devlin, S., Syväranta, J., \& Jones, R. (2017). Influence of littoral periphyton on whole-lake metabolism relates to littoral vegetation in humic lakes. Ecology, 98 (12), 30743085. doi:10.1002/ecy.2012

Vuorenmaa, J., Forsius, M. \& Mannio, J. (2006). Increasing trends of total organic carbon concentrations in small forest lakes in Finland from 1987 to 2003. Science of the Total Environment, 365, 47.

Zuur, A. F., Ieno, E. N., Walker, N. J., Saveliev, A. A. \& Smith G. M. (2009). Mixed effects models and extensions in ecology with R. Statistics for Biology and Health. Springer-Verlag New York, New York, NY, United States, pp. 544. 
Table 1 Results of the Linear and Generalized mixed models (LMM and GLMM). Lake was set as random effect to account for spatial autocorrelation. Nobs stands for Number of observations and Nlake for Number of lakes included in the analysis. Water color was square root transformed prior to analysis when used as a response variable. "m" stands for marginal and "c" for conditional when referring to the coefficient of determination $\mathrm{R}^{2}$ from LMM and GLMM (see methods).

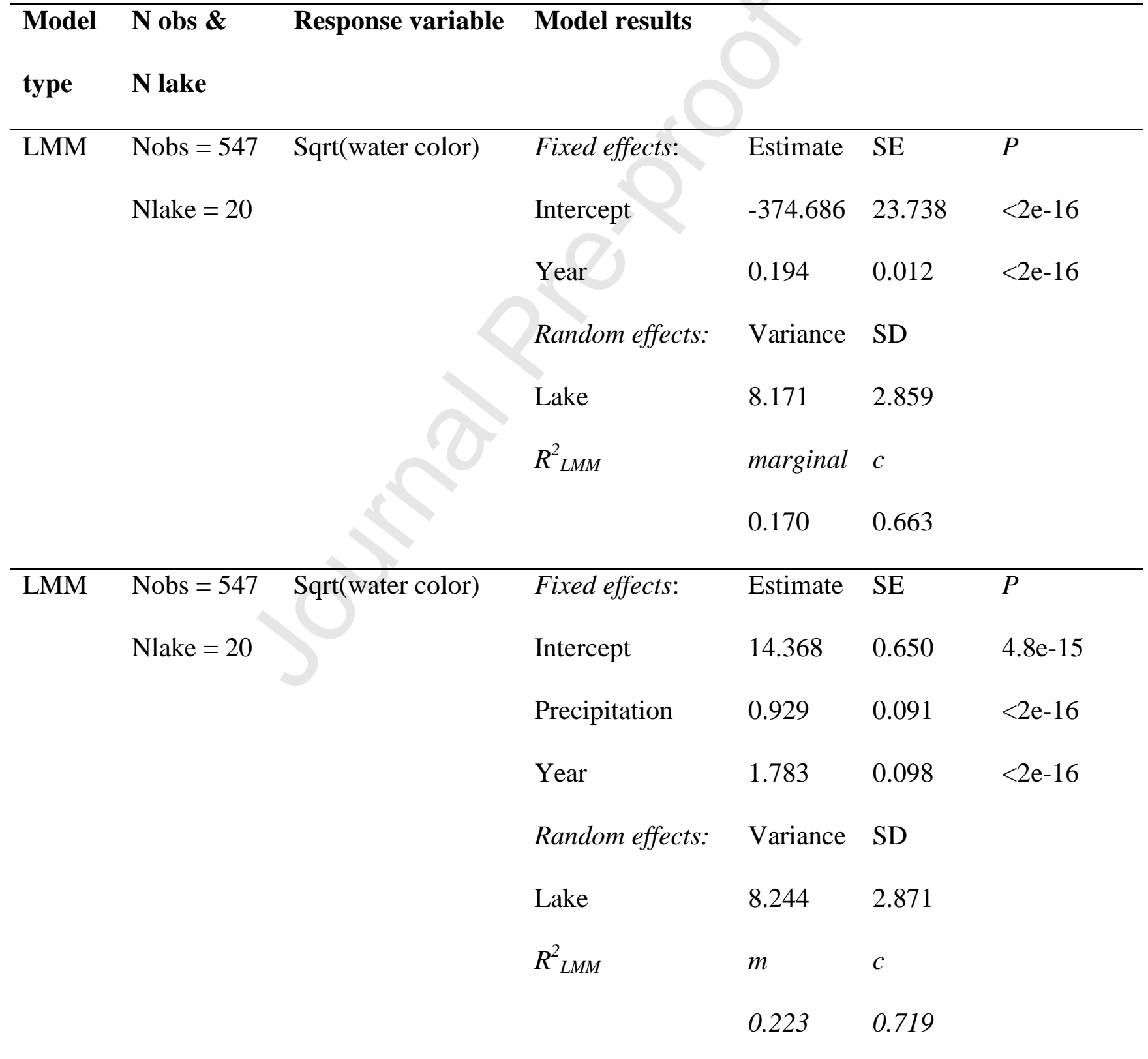




\begin{tabular}{|c|c|c|c|c|c|c|}
\hline \multirow[t]{7}{*}{ LMM } & Nobs $=142$ & Sqrt(water color) & Fixed effects: & Estimate & SE & $P$ \\
\hline & Nlake $=5$ & & Intercept & -477.046 & 38.587 & $<2 \mathrm{e}-16$ \\
\hline & & & Year & 0.246 & 0.019 & $<2 \mathrm{e}-16$ \\
\hline & & & Random effects: & Variance & SD & \\
\hline & & & Lake & 2.648 & 1.627 & \\
\hline & & & $R_{L M M}^{2}$ & $m$ & $c$ & \\
\hline & & & & 0.399 & 0.656 & \\
\hline \multirow[t]{8}{*}{ Poisson } & Nobs $=91$ & Invertebrate & Fixed effects & Estimate & SE & $P$ \\
\hline & Nlake $=5$ & abundance & (Intercept) & 3.331 & 0.215 & $<2 \mathrm{e}-16$ \\
\hline & & & Water color & -0.443 & 0.039 & $<2 \mathrm{e}-16$ \\
\hline & & & Year & -0.058 & 0.033 & 0.077 \\
\hline & & & Random effects: & Variance & SD & \\
\hline & & & Lake & 0.229 & 0.478 & \\
\hline & & & $R_{G L M M}^{2}$ & $m$ & $c$ & \\
\hline & & & & 0.470 & 0.470 & \\
\hline \multirow[t]{8}{*}{ LMM } & Nobs $=91$ & Invertebrate & Fixed effects: & Estimate & $\mathrm{SE}$ & $P$ \\
\hline & Nlake $=5$ & richness & (Intercept) & 4.349 & 0.303 & $<2 \mathrm{e}-04$ \\
\hline & & & Water color & -0.101 & 0.260 & 0.700 \\
\hline & & & Year & -0.359 & 0.243 & 0.143 \\
\hline & & & Random effects: & Variance & SD & \\
\hline & & & Lake & 0.341 & 0.584 & \\
\hline & & & $R_{L M M}^{2}$ & $m$ & $c$ & \\
\hline & & & & 0.067 & 0.196 & \\
\hline
\end{tabular}


Figure legend

Figure 1 Location of the study sites. A) Location of the Evo Natura 2000 area within Finland. B) Location of the 20 studied lakes within the study area.

Figure 2. Changes in average water color (mean \pm SD) from 1988 to 2018 in the 20 lakes for which the main water color analysis was conducted (gray circle) (see main text) and in the five lakes for which invertebrate data were available (black circle). The period during which invertebrate abundance and richness were recorded is delimited by the dashed lines. Note that only lake "Nimetön" was sampled in 1979, 1980 and 1983, two lakes were sampled in 1987, nine lakes in 1988, four in 1989, 10 in 1990, and 17 to 20 lakes per year for the following years (See Table S1).

Figure 3. Annual average a) invertebrate abundance and b) invertebrate richness in relation to water color for the five lakes studied. 
Figure 1

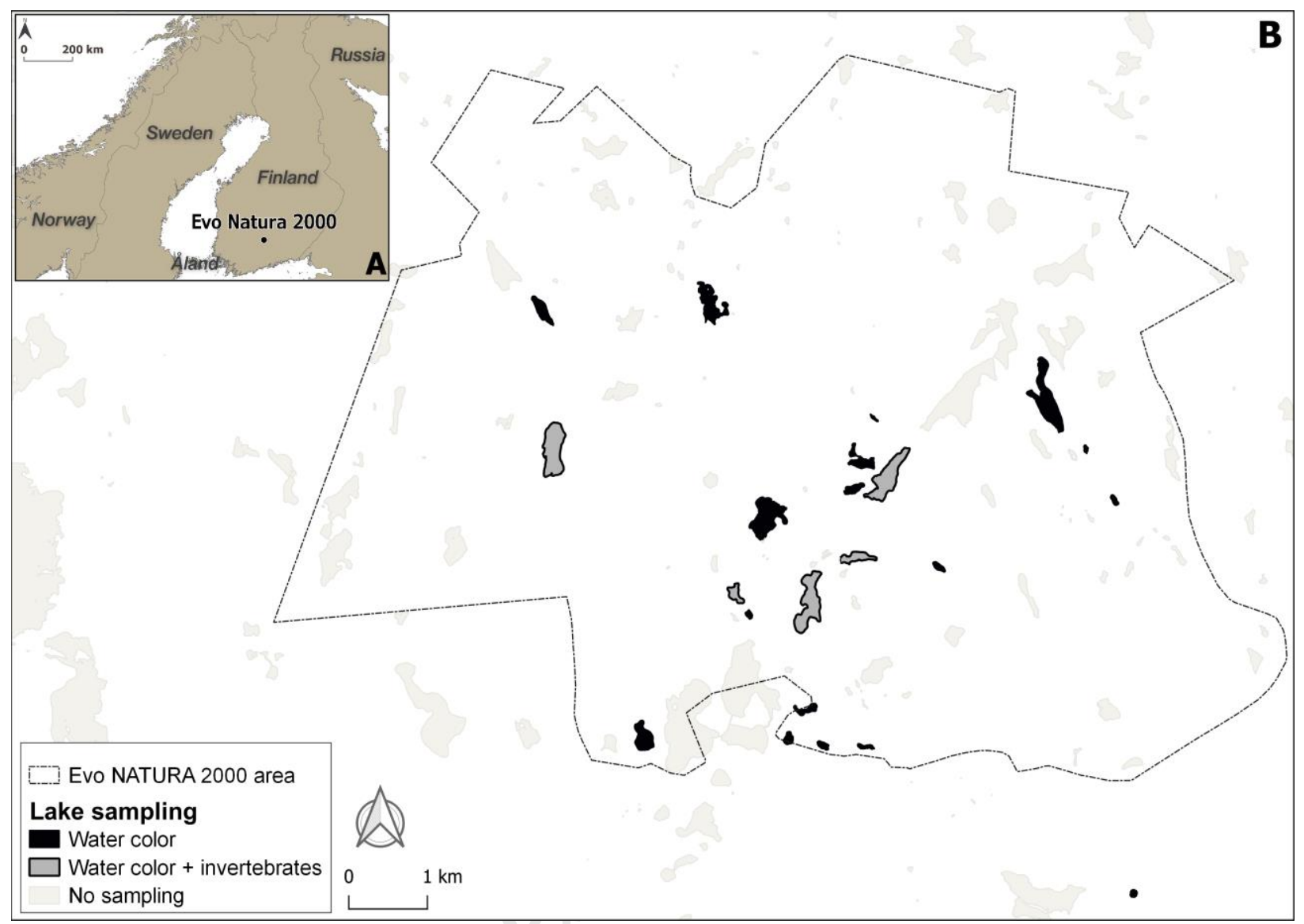

Figure 1 Location of the study sites. A) Location of the Evo Natura 2000 area within Finland. B)

Location of the 20 studied lakes within the study area. 


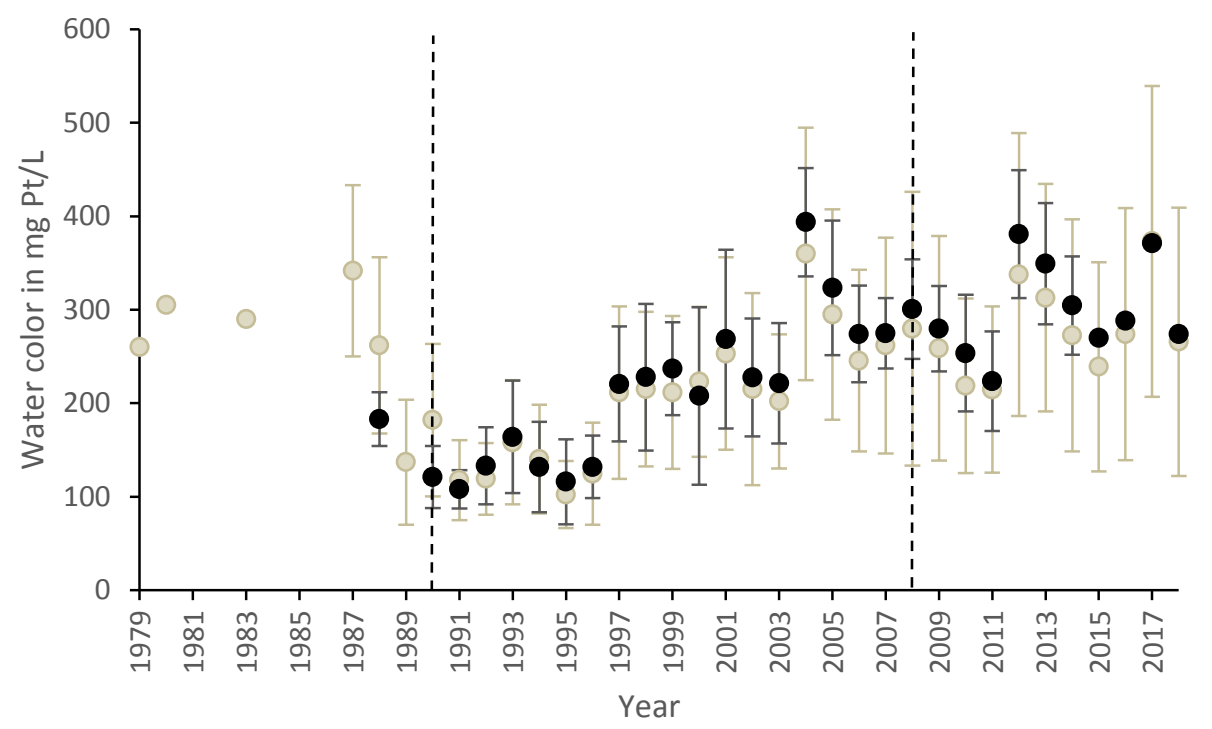

Figure 2. Changes in average water color (mean \pm SD) from 1988 to 2018 in the 20 lakes for which the main water color analysis was conducted (gray circle) (see main text) and in the five lakes for which invertebrate data were available (black circle). The period during which invertebrate abundance and richness were recorded is delimited by the dashed lines. Note that only lake "Nimetön" was sampled in 1979, 1980 and 1983, two lakes were sampled in 1987, nine lakes in 1988, four in 1989, 10 in 1990, and 17 to 20 lakes per year for the following years (See Table S1). 
a)

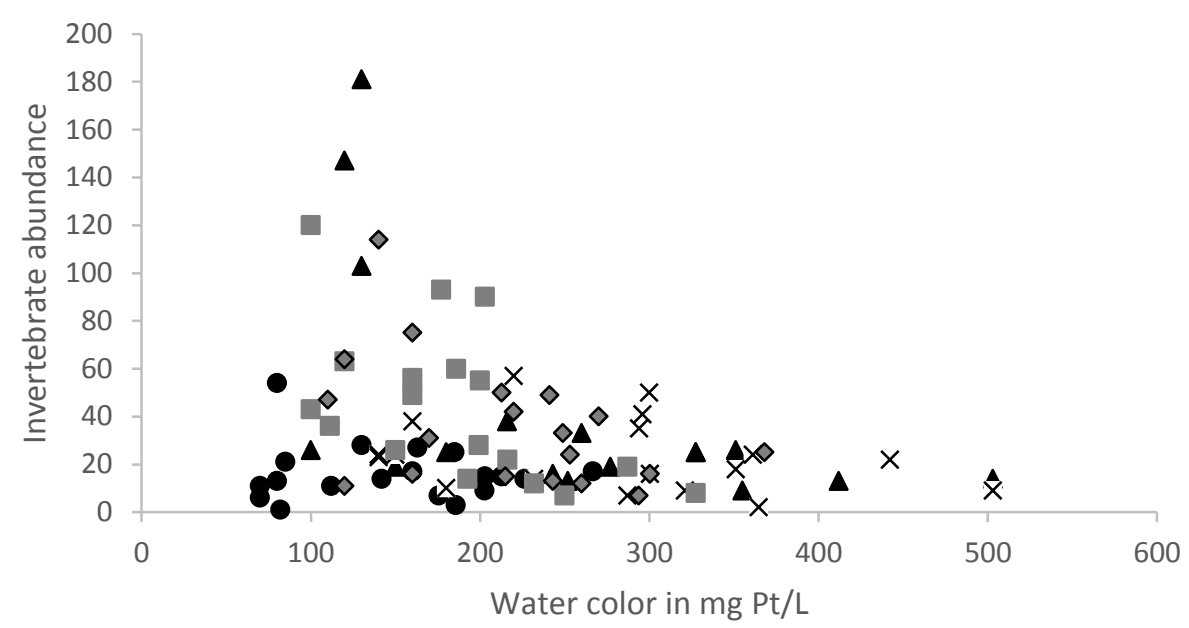

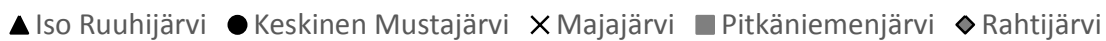

b)

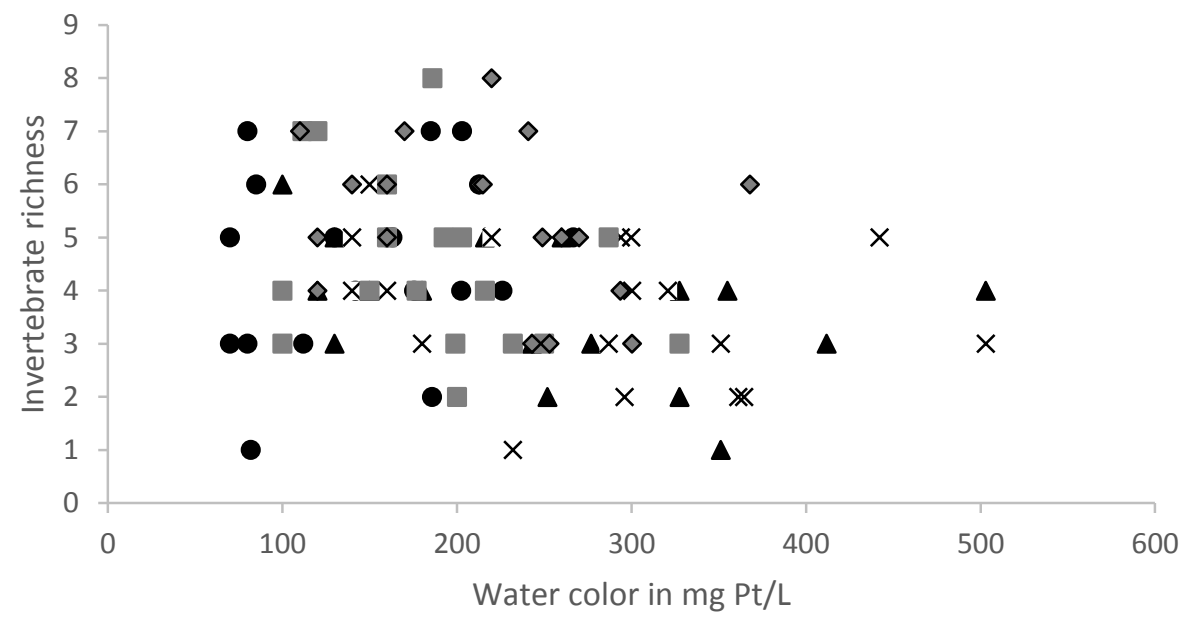

$\Delta$ Iso Ruuhijärvi @ Keskinen Mustajärvi ×Majajärvi Ditkäniemenjärvi $\diamond$ Rahtijärvi

Figure 3. Annual average a) invertebrate abundance and b) invertebrate richness in relation to water color for the five lakes studied. 


\section{Author contributions}

CA and PN designed the study. CA gathered and analyzed the data, with support and feedback

from PN, SH \& LA. AD provided Figure 1. CA wrote the manuscript and all co-authors provided editorial revisions. 


\section{Declaration of interests}

$\bigotimes$ The authors declare that they have no known competing financial interests or personal relationships that could have appeared to influence the work reported in this paper.

$\square$ The authors declare the following financial interests/personal relationships which may be considered as potential competing interests: 
Table 1 Results of the Linear and Generalized mixed models (LMM and GLMM). Lake was set as random effect to account for spatial autocorrelation. Nobs stands for Number of observations and Nlake for Number of lakes included in the analysis. Water color was square root transformed prior to analysis when used as a response variable. "m" stands for marginal and "c" for conditional when referring to the coefficient of determination $\mathrm{R}^{2}$ from LMM and GLMM (see methods).

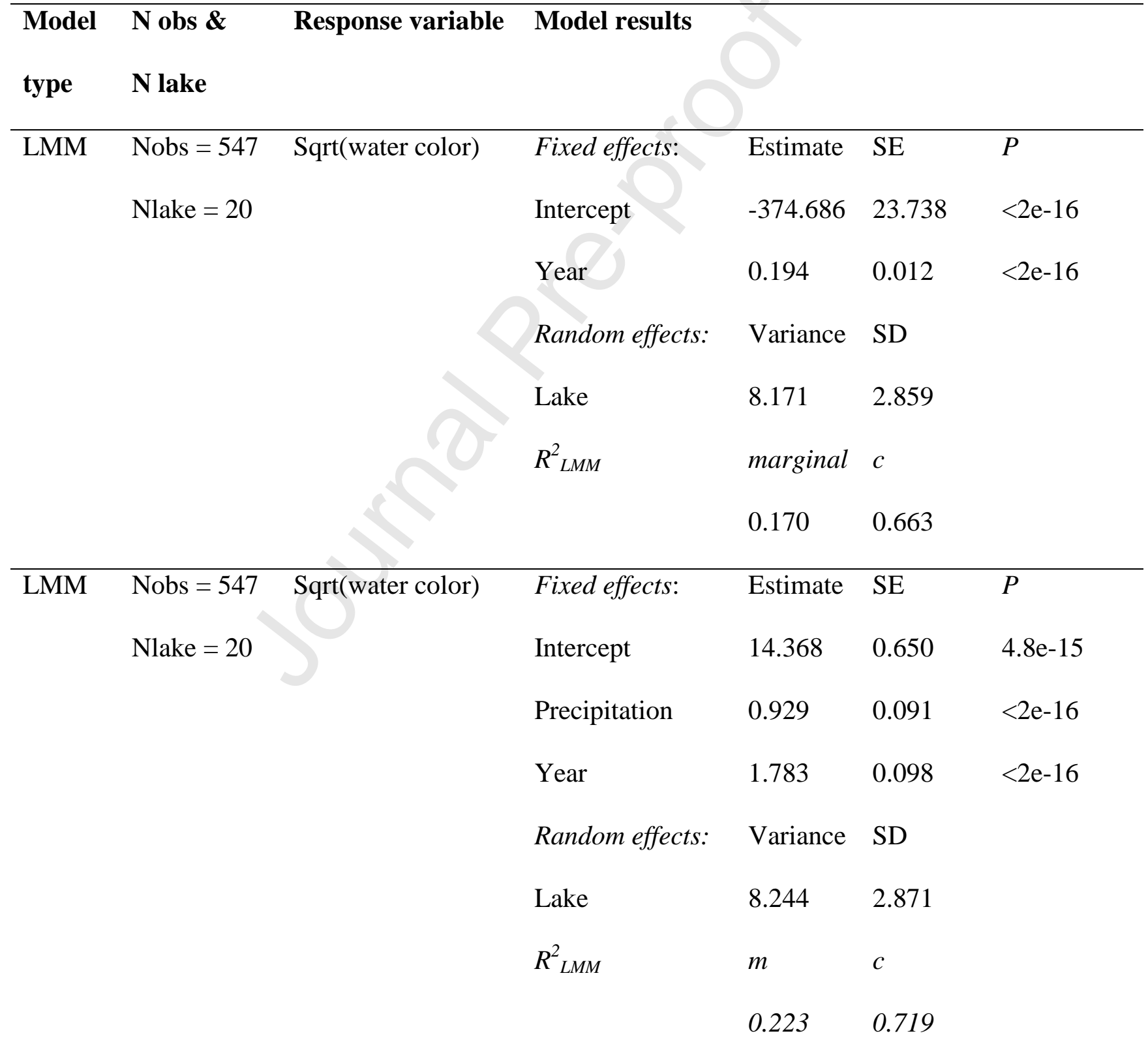




\begin{tabular}{|c|c|c|c|c|c|c|}
\hline \multirow[t]{7}{*}{ LMM } & Nobs $=142$ & Sqrt(water color) & Fixed effects: & Estimate & SE & $P$ \\
\hline & Nlake $=5$ & & Intercept & -477.046 & 38.587 & $<2 \mathrm{e}-16$ \\
\hline & & & Year & 0.246 & 0.019 & $<2 \mathrm{e}-16$ \\
\hline & & & Random effects: & Variance & SD & \\
\hline & & & Lake & 2.648 & 1.627 & \\
\hline & & & $R_{L M M}^{2}$ & $m$ & $c$ & \\
\hline & & & & 0.399 & 0.656 & \\
\hline \multirow[t]{8}{*}{ Poisson } & Nobs $=91$ & Invertebrate & Fixed effects & Estimate & SE & $P$ \\
\hline & Nlake $=5$ & abundance & (Intercept) & 3.331 & 0.215 & $<2 \mathrm{e}-16$ \\
\hline & & & Water color & -0.443 & 0.039 & $<2 \mathrm{e}-16$ \\
\hline & & & Year & -0.058 & 0.033 & 0.077 \\
\hline & & & Random effects: & Variance & SD & \\
\hline & & & Lake & 0.229 & 0.478 & \\
\hline & & & $R_{G L M M}^{2}$ & $m$ & $c$ & \\
\hline & & & & 0.470 & 0.470 & \\
\hline \multirow[t]{8}{*}{ LMM } & Nobs $=91$ & Invertebrate & Fixed effects: & Estimate & $\mathrm{SE}$ & $P$ \\
\hline & Nlake $=5$ & richness & (Intercept) & 4.349 & 0.303 & $<2 \mathrm{e}-04$ \\
\hline & & & Water color & -0.101 & 0.260 & 0.700 \\
\hline & & & Year & -0.359 & 0.243 & 0.143 \\
\hline & & & Random effects: & Variance & SD & \\
\hline & & & Lake & 0.341 & 0.584 & \\
\hline & & & $R_{L M M}^{2}$ & $m$ & $c$ & \\
\hline & & & & 0.067 & 0.196 & \\
\hline
\end{tabular}


Graphical abstract

Invertebrates

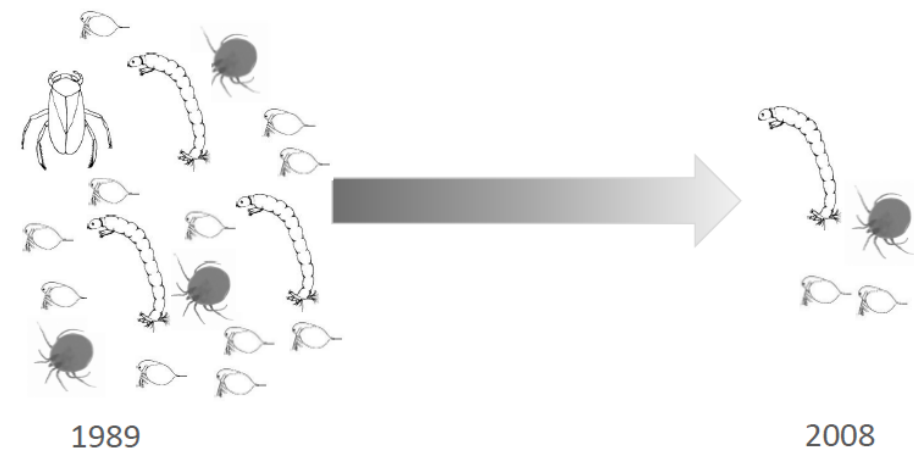

Brownification 


\section{Highlights}

- Water became browner in all studied lakes within 3 decades.

- Increased precipitation explains only partly the increase in water color.

- No significant change of invertebrate richness was linked to water color increase.

- Aquatic macroinvertebrate abundance declined with water color increase. 